\title{
ROLE OF CHILD MONITORING CENTERS IN THE EVALUATION OF CHILD SEXUAL ABUSE
}

\author{
Aslı YAYAK \\ Bursa Technical University, Turkey
}

\section{Introduction}

Children, by their basic characteristics, are known as the group that most in need of protection in both physical and psychological aspects. Both in Turkey and in other countries around the world, child abuse and negligence are examples of frequently encountered ill-treatment. This abuse and neglect for children has been regarded as a cultural situation among societies for many years and has been ignored as a condition that must remain within the family unity. The size of the traumatic situation in the recent years has now emerged with the examples reflected in the press. Thus, in order to protect the best interests of the child in our country, it has been tried to be strengthened by making legal arrangements especially in recent years. The fact that our children have a healthy childhood has a crucial importance for the future of our country.

Child neglect and abuse, as defined by the World Health Organization (WHO) in its widest definition, are bad behaviors that result in physical / emotional / sexual abuse, neglect and other forms of abuse, which adversely affect the health, survival, development or trust in children under the age of 18. Yet, according to 
WHO data, it is stated that $25 \%$ of adults are physically abused in childhood, $20 \%$ of women and $8 \%$ of men are exposed to sexual abuse in their childhood. In addition, it is reported that 31,000 children under 15 years of age in the world lose their lives due to child abuse (WHO, 2016).

The reports of sexual abuse for both boys and girls, often reflected in the press in recent times, are only the visible part of the iceberg. It is estimated that the actual figures are much more than the number reaching the officials.

Children are the group most frequently exposed to neglect and abuse because they do not have sufficient power to protect themselves. Accordingly, they are the group that needs to be protected and supported the most. At this point, the definition of the concept of child is seen as an important premise. All kinds of children's physical, psychological, including the Convention on the Rights of the Child sexual abuse and neglect prevention, including Turkey was signed by 197 countries and has gained the status of the law on 2nd September 2010 (Kurt, 2016). According to the first article of the Convention on the Rights of the Child (1989), according to the law applicable to the child, every person until the age of eighteen is considered to be a child. This indicates that every individual between the ages of 0-18 should be accepted as children and that the rights of their basic life should be protected.

The notion of child neglect and abuse encapsulates; all physical, emotional or sexual attitudes, such as the parents of children who are responsible for looking after them, by causing harm to their physical and / or psychological health by persons or foreigners with whom they have a relationship of responsibility, power and trust (Şahin, 2006). All conditions where the health or well-being of a child under the age of 18 are harmed or threatened are considered in the context of child neglect and abuse (Child Welfare Information Cateway, 2016). In the context of these definitions and assessments, the World Health Organization (WHO, 2016) has separated child maltreatment into four groups: physical abuse, emotional / psychological abuse, sexual abuse and neglect.

Children's mental health is seriously damaging by child abuse especially sexual abuse. Psychiatric disorders were observed in the majority of children evaluated after sexual abuse (Şimşek et al., 2011; Soylu et al., 2012).

In the absence of material evidence, the perpetrators have been unable to prove their actions. Victims are more victims because they cannot prove their victimization and they are trying to survive as unhealthy people. The existence of a team work is very important in order not to have all of this. Child monitoring centers established in our country have been established to evaluate this problem.

In this research, it is aimed to give information about the processing and structure of child monitoring centers operating in our country since 2010 and evaluation process of sexual abuse of the child. 


\section{Method}

In this study, a literature survey about the Child Monitoring Centers in our country has been made and related information has been gathered.

\section{Findings}

Child abuse in childhood traumas is a form of trauma that is the most difficult to identify and treat because it is reproducible and is mostly performed by the child's closest ones.

The World Health Organization (2002) explained the definition of child abuse as follows: including all forms of commercial advertising or any other form of influence that will cause any physical / emotional / sexual abuse / neglect that may cause a negative impact on the child's health, growth and development. Different types of abuse can be seen at the same time, a child who has been sexually abused and physically abused at the same time, and/or physically abused may also be exposed to emotional abuse (Tiraşçı and Gören, 2007).

According to Glaser (1991), the most commonly used definition of sexual abuse; "Developmental immature children and adolescents cannot fully understand, are not informed or consent to participate in sexual activities that violate social taboo and family roles" (Taneli et al., 1999; Doğan, 2009). All actions such as incest, rape, attempted rape, disclosure molestation and expulsion are considered within the context of sexual abuse (Akdoğan, 2005). The child's sexual abuse is undoubtedly a very traumatic event that has influenced the child's entire life. In the international literature, $10-34 \%$ of girls and 3-18\% of boys are sexually abused (Wyatt et al., 1999). In our country, there are studies showing that sexual abuse is in the 11-37\% range under the age of 18 (Örsel et al., 2011; Alikaşifoğlu et al., 2006).

The most common forms of child sexual abuse are child pornography, incest and child rape. Incest is the type of sexual abuse that has the most effect on the child (Akdoğan, 2005). Incest has very destructive effects on the child because it is carried out by family members. Incest as literature provision; marriages are legally, morally and religiously prohibited in terms of male and female sexual relations with close relatives (Akduman et al., 2005). It is often an ignored situation because it is a family issue.

In our country, the abused child and / or family have a tendency to keep the abused state for many reasons and legal, medical, psychological and social support which must be given to the abused child is not given to the extent required. Due to the lack of cooperation and coordination among the law enforcement agencies, judicial authorities and health institutions, victims are to be evaluated separately and 
repeated questions, forced to express their experiences in inappropriate conditions, not to provide confidentiality, the professional in the relevant institutions with the mental status of the child to be able to interview the qualifications and education various reasons, such as absence, may intensify the trauma experienced by the child and make it difficult to treat the child mentally.

In order to reduce the effect of possible crimes, traumas, prevent secondary trauma and to intervene in a conscious and effective way for children who have been abused, it was found appropriate to establish Child Monitoring Centers and to carry out the operation of these centers under the coordination of the Ministry of Health in order to ensure that they are carried out in a single center of trained persons and to take preventive measures. Ministry of Justice, Ministry of Family and Social Policies, Ministry of Interior (General Directorate of Security and General Command of Gendarmerie), Ministry of National Education, Directorate of Religious Affairs, Office of Forensic Medicine and Bench started a study in Ankara in 2010 Child Monitoring Center was established as a pilot center (Bağ and Alşen, 2016).

There are people from different occupational groups working in child monitoring centers. The forensic interviewer, the family interviewer, the representative of the Provincial Directorate of Family and Social Policies, the nurse and the responsible physician are working. Forensic interviewer completes his / her education and forensic interview with the child during this process, considering the child's development, psychological characteristics and the effects of trauma in the child who can be a psychologist, physician, psychological counselor, nurse, social worker or child development specialist. During the forensic interview, the information about the incident is attempted to clarify the incident and a forensic report is prepared as a result of the interview. The family interviewer talks to the parents of the child who is suspected of abuse and provides counseling services to their parents. In these centers, the forensic interviewer and the family interviewer participate in the "Forensic Interviewer Certified Training Program" organized by the Ministry of Health and receive certificates. The representative of the Provincial Directorate of Family and Social Policies is involved in situations where risky situations are observed. He/she conducts a social examination report for the children who should be sent to the orphanage. The nurse provides health checks by organizing all examinations. The responsible physician is responsible for the planning and execution of the services (Bağ and Alşen, 2016).

These centers work on the principle of 7 days 24 hours. For this reason, a forensic interviewer is on duty every day. There are two rooms with bath and beds in order to accommodate overnight stays.

Firstly, an interview is made with a child coming to the center. It is aimed to meet the child and to gain the trust and to introduce the center. On the other hand, the 
family interviewer discusses with the family or the child's companion. A lawyer request is made from Bench to prepare for forensic interview.Forensic interview is an interview held in a mirrored room with semi-structured questions. In the room on the back side of the mirror, there is a prosecutor, lawyer, family interviewer and the representative of the Provincial Directorate of Family and Social Policies. The forensic interviewer tries to learn the details of the incident and the identity of the exploiter with various questions in accordance with the age of the child. The main purpose here is to obtain the necessary information from the child for other professionals. The interview is recorded with video and audio. At the end of the interview, a short training is given, which is reminiscent of the child's body. During the meeting, the representative of each institution keeps its records, but one written record of the interview is signed. The investigation by the prosecution is initiated by this report. This interview is adapted to a report by the forensic interviewer who made the interview and added to the child's file in the legal process (Bağ and Alşen, 2016).

After the interview, the child is taken to the forensic examination room and examined by a nurse. After the confirmation of the child is taken, if necessary, the internal body examination is performed by the forensic medicine specialist. These examinations are recorded by video coloscope to avoid having multiple examinations. In the center, the pediatrician also carries out a general health examination of the child and the necessary treatments are applied. If the child does not have a safe place to return to, the child is placed to an orphanage by representative of the Provincial Directorate of Family and Social Policies.

\section{Result}

Child monitoring centers are centers established by the Ministry of Health to minimize secondary harassment of children who have been sexually abused, and to ensure that the forensic and medical procedures are carried out in a center consisting of trained people in this field. Sexual abuse is suspected of receipt of the declaration of the child, conducting examinations, family discussions of where all the staff and equipment required for the preparation of and reports made, the operation of each stage in the child's best interest in considering conducted by these centers, serves 31 active centers in 28 different cities in Turkey at the moment.

In a study of the Ministry of Justice, the child had to make an explanation 17 times during the expression process after the abuse (Akço et al., 2013). Child monitoring centers are also centers established to prevent the child from making repeated statements.

The main objective is to prevent the child from making explanations again and again about his situation in the process that begins with the arrival of the child. On the other hand, by gathering the stakeholder institutions under a single roof, 
transactions are carried out in a faster and more organized way. Yet, working with different professions, develops professional approaches by sharing professional experiences. All transactions in the center are carried out in complete confidentiality.

If professional staff obtains information or suspects that a child has been sexually abused, he or she has to report to law enforcement or the public prosecutor's office. The police force receiving the notification will send the child to the center. In addition, professionals and families can apply directly to the center for consultation or they can redirect the child for it. 


\section{References and notes:}

Alikaşifoğlu, M., Erginöz, E., Ercan, O., Albayrak-Kaymak, D., Uysal, Ö. \& İlter, Ö. (2006). Sexual abuse among female high-school students in İstanbul, Turkey. Child Abuse \& Neglect, 30, 247-255.

Akço, S., Dağl1, T., İnanıcı, M.A., Kaynak, H., Oral, R., Şahin, F. et al. (2013). Child abuse and neglect in Turkey: professional, governmental and non-governmental achievements in improving the national child protection system. Paediatrics and International Child Health, 33(4), 301-309.

Akdoğan, H. (2005). Studies on Prevention of Sexual Abuse of Child and Child Sexual Abuse in Turkey. Polis Bilimleri Dergisi, 7 (1), 1-16.

Akduman, G., Ruban, C., Akduman, B. \& Korkusuz, İ. (2005). Child Abuse and Negligence: Psychiatric Aspects. Adli Psikiyatri Dergisi, 3, 9-14.

Bağ, Ö. \& Alşen, S. (2016). A new model in evaluating child sexual abuse: Child Advocacy Centers. İzmir Dr. Behçet Uz Çocuk Hastanesi Dergisi,6(1), 9-14.

Child Welfare Information Cateway. (2016). https://www.childwelfare.gov/

Convention on the Rights of the Child. (1989). United Nations General Assembly.

Doğan, Ö. (2009). Investigation of the Effects of Formation of Psychiatric Disorder and Abused by the Definition of Individual, Familial and Features of Abuse among Sexual Abused Adolescents: A Controlled Study. Dokuz Eylül University, İzmir.

World Health Organization. (2002). World Health Report: Reducing the Risks, Enhancing the Healthy Life. http://www.ttb.org.tr/halk_sagligi/BELGELER/Dunya_Saglik_Raporu_2002.

Kurt, S.L. (2016). Basic International Documents concerning Child Rights and Turkey Application. Sosyal Politika Çalışmaları Dergisi,16(1), 99-127.

Örsel, S., Karadağ, H., Karaoğlan Kahiloğulları, A. \& Akgün-Aktaş, E. (2011). Frequency Childhood Traums among Psychiatry Traumas and Relationship with Psychopathology. Anatolian Journal of Psychiatry, 12,130-136.

Soylu, N., Pilan, B.Ş., Ayaz, M. \& Sönmez, S. (2012). Study of factors affecting mental health in sexually abused children and adolescent. Anatolian Journal of Psychiatry, 13 (4), 292-298.

Şahin, F. (2006). Definition of Child Abuse, Epidemiology and Importance of Multidisciplinary Team Approach. Çocuk İstismarı ve İhmaline Multidisipliner Yaklaşım, 5-11, Ankara Üniversitesi Basımevi.

Şimşek, Ş., Fettahoğlu, E.Ç. \& Özatalay, E. (2011). Post-traumatic Stress Disorder in Sexually Abused Children and Parents. Dicle Tip Dergisi, 38(3).

Taneli, S., Albayrak, E.C. \& Sivrioğlu, E.Y. (1999). Sexual Abuse of Infant and Diagnosis Challenges. Aysel Ekşi.(Ed.), in I am not Patient: Psychosocial Aspect of Child Health and Diseaases (531-541). İstanbul: Nobel Tıp Kitapevi.

Tıraşçı, Y. \& Gören, S. (2007). Child Abuse and Negligence. Dicle Tip Dergisi,34(1),7074.

World Health Organization. (2016). Child Maltreatment. http://www.who.int/mediacentre/factsheets/fs150/en/.

Wyatt, G. E., Loeb, T. B., Solis, B., Carmona, J. V. \& Romero, G. (1999). The prevalence and circumstances of child sexual abuse: Changes across a decade. Child Abuse \& Neglect, 23(1), 45-60. 


\section{XÜLASə}

\section{Uşaqlara qarşı cinsi istismarın dəyərləndirilməsində Monitorinq mərkəzlərinin rolu}

\section{Asli YAYAK \\ Bursa Texniki Universiteti, Türkiyə}

Yetişkin bir şəxs tərəfindən cinsi və psixoseksual cəhətdən məmnunluğunu tamamlamaq üçün bir uşaqdan sui-istifadə etməsi , uşağa qarş1 cinsi istismar sayılır. Uşaqlar, təməl xüsusiyyətləri ilə həm fiziki, həm də psixoloji baxımdan qorunmağa ən çox ehtiyacı olan qrup kimi tanınır. Bu məqalədə, 2010-cu ildən bu vaxta qədər ölkəmizdə fəaliyyət göstərən Uşaq Monitorinq mərkəzlərinin fəaliyyət göstərməsi , uşaqlara qarşı cinsi istismar prosesini dəyərləndirmək üçün əsas mərkəzlərdir.

Uşaq Monitorinq Mərkəzləri, cinsi istismar nəticəsində şübhə altına alınan uşaqlardan məlumat almaq, ailələri ilə tanışmaq və digər işlərlə bağlı hesabatları hazırlamaq üçün xüsusi ekspertlərin fəaliyyət göstərdiyi mərkəzlərdir. Türkiyənin 28 fərqli bölgəsində 31 bu cür mərkəz işləyir. Psixiloqlar, Sosial xidmət üzrə mütəxəssislər, Uşaq inkişaf ekspertləri, həkim , tibb bacıları və Uşaq psixoloqları bu mərkəzlərdə davamlı olaraq çalışırlar. Burada; məhkəmə-tibbi görüşlər, ailə görüşləri, məhkəmə ekspertizaları və psixiatrik qiymətləndirmələr aparılır.

Açar sözlər: Uşaq, cinsi istismar, Uşaq monitorinq mərkəzi, zorakılıq, ekspert 


\title{
PEЗЮМЕ
}

\section{Роль центров Мониторинга в оценке сексуального насилия против детей}

\author{
Аслы ЯЙЯк \\ Бурсский технический университет, Турция
}

\begin{abstract}
Жестокое обращение с ребенком со стороны взрослого человека с целью его сексуального и психосексуального удовлетворения называется сексуальным насилием над ребенком. Известно, что дети из-за их основных характеристик являются группой, наиболее нуждающейся в защите как физически, так и психологически. В этой статье указанно, что деятельность Центров детского мониторинга, действующих в нашей стране с 2010 года, является основным центром оценки процесса сексуальное эксплуатации над детьми.
\end{abstract}

Центры детского мониторинга - это специализированные центры для получения информации от детей, подозреваемых в сексуальной эксплуатации, посещения их семей и подготовки отчетов о других мероприятиях. В 28 различных регионах Турции, функционируют 31 таких центров. В этих центрах регулярно работают психологи, социальные работники, эксперты по развитию ребенка, врачи, медсестры и детские психологи. Здесь, проводятся судебномедицинские встречи, семейные встречи, судебно-медицинские экспертизы и психиатрические обследования.

Ключевые слова: Ребенок, сексуальное эксплуатация, центр детского мониторинга, насилие, эксперт 